\title{
Ribosome-Inactivating Protein CY503
}

National Cancer Institute

\section{Source}

National Cancer Institute. Ribosome-Inactivating Protein CY503. NCI Thesaurus. Code C78188.

A recombinant protein that inactivates the ribosome with potential antineoplastic and immunomodulating activities. Ribosome-inactivating protein CY503 binds to the cell surface sialyltransferase CD75 and is internalized; intracellularly, CY503 cleaves an adenine-specific $\mathrm{N}$-glycosidic bond on the $28 \mathrm{~S}$ ribosomal subunit, which may result in tumor cell apoptosis. This agent has also been shown to activate natural killer (NK) cells, induce cytokine receptor expression, and stimulate the release of cytokines. CD75 is expressed on mature B-cells and subsets of T-cells and erythrocytes. 